\title{
KONSUMSI PERMEN SUSU MEMPENGARUHI PENURUNAN KONSUMSI ROKOK PADA REMAJA
}

\author{
Siska Mayang Sari ${ }^{1}$, Trisna ${ }^{2}$, T. Abdur Rasyid ${ }^{3}$ \\ ${ }^{1,2,3}$ Program Studi Ilmu Keperawatan Sekolah Tinggi Ilmu Kesehatan Hang Tuah Pekanbaru \\ Email : siska_myg@yahoo.com
}

\begin{abstract}
Abstrak
Perilaku merokok merupakan masalah kesehatan dunia karena dapat menyebabkan berbagai penyakit dan kematian. Perilaku merokok pada usia remaja menjadi tren yang harus diatasi. Tujuan penelitian ini adalah untuk mengetahui pengaruh konsumsi permen susu terhadap penurunan konsumsi rokok pada remaja. Desain penelitian ini adalah Quasi Eksperimen dengan rancangan pretest-posttest with control group. Sampel berjumlah 32 orang dengan teknik pengambilan sampel stratified random sampling. Instrumen penelitian ini adalah lembar observasi dan kuesioner sebagai data pendukung. Analisis yang digunakan adalah analisis univariat dan analisis bivariat dengan uji Wilcoxon dan Mann Whitney. Hasil penelitian ini menunjukkan mayoritas responden berada pada rentang usia 16-18 tahun (Remaja pertengahan) sebanyak 27 orang $(84,4$ $\%)$, mayoritas responden dengan kategori perokok ringan sebanyak 23 orang (71,9\%), mayoritas lama merokok responden $<2$ tahun sebanyak 28 orang $(87,5 \%)$, dan mayoritas responden dengan alasan merokok coba-coba sebanyak 16 Orang (50,0\%). Hasil penelitian menunjukkan terdapat perbedaan yang signifikan rata-rata penurunan konsumsi rokok sebelum dan sesudah konsumsi permen susu pada kelompok eksperimen ( $\mathrm{p}$ value $=0,000$ ), tidak terdapat perbedaan yang signifikan penurunan konsumsi rokok pada kelompok kontrol ( $\mathrm{p}$ value $=0,083$ ), dan terdapat perbedaan yang signifikan rata-rata penurunan konsumsi rokok antara kelompok eksperimen dan kelompok kontrol $(\mathrm{p}$ value $=0,000)$ yang berarti permen susu berpengaruh terhadap penurunan konsumsi rokok. Penelitian ini menyarankan agar remaja perokok dapat menggunakan permen susu sebagai terapi alternatif nonfarmakologis untuk menurunkan jumlah konsumsi rokok.
\end{abstract}

Kata Kunci: Permen Susu, Penurunan Konsumsi Rokok, Remaja

\section{Abstract}

The smoking behavior is a health problem of the world because it can cause morbidity and mortality. Smoking behavior in adolescents is become a trend so, it should to resolved. The purpose of this research was to know the influences of milk candy consumption toward cigarette consumption reduction in adolescents. This was a quantitative study with Quasi Experimental design and pretest-posttest design with control group approach. The sample were 32 persons which taken by stratified random sampling technique. The instrument were observation sheet and questionnaire as supporting data. Data analysis used univariate and bivariate with Wilcoxon and Mann Whitney test. The result showed that majority in respondents were in age range of 16-18 years (mid-teens) 27 people (84,4\%), majority of respondents in mild smoker category as many as 23 people (71,9\%), majority of smoke less than 2 years as many as 28 people (87,5\%), and majority respondents reason curious try as many as 16 people (50,0\%). There was a significant difference cigarette consumption reduction before and after milk candy consumption in experiments group ( $p$ value $=0,000$ ), but not in control group ( $p$ value $=0,083$ ), and there was significant difference of mean cigarette consumption reduction between experiments and control group ( $p$ value $=0,000)$ that mean there was influence of milk candy toward reduction of cigarette. This research suggest that smoker adolescents can use mild candy as alternative therapy nonfarmacologies in reduction of smoking consumption.

Keywords: Milk Candies, Decline in Cigarette Consumption

\section{PENDAHULUAN}

Risiko penyebab kanker paru adalah merokok. kebiasaan merokok berhubungan dengan sekitar 70 persen kematian akibat kanker paru, (Maharani, 2015). Merokok telah diketahui dapat menimbulkan masalah yang serius, karena selain menyangkut masalah aspek kesehatan, merokok juga menyangkut 


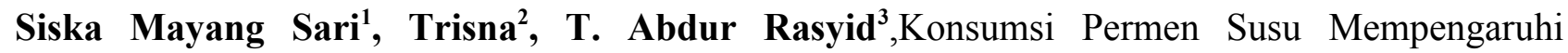
Penurunan Konsumsi Rokok Pada Remaja

aspek ekonomi sosial. Indonesia adalah salah satu negara dengan jumlah perokok terbesar di dunia setelah China yaitu sekitar 1,643 miliar batang, Amerika Serikat 451 miliar batang, Jepang 328 miliar batang, dan Rusia 258 miliar batang setiap tahunnya. Jumlah batang rokok yang dikonsumsi di Indonesia berkisar 215 miliar batang rokok setiap tahunnya (Tarwoto dkk., 2012).

Dari data World Health Organization (WHO) tahun 2014, epidemi tembakau telah membunuh sekitar 6 juta orang pertahun, dimana 600 ribu diantaranya merupakan perokok pasif. Jika tidak ada penanganan yang serius, maka pada tahun 2030 diperkirakan jumlah korban akan semakin bertambah menjadi 8 juta orang dan sebagian besar terjadi di negara-negara berkembang (Adystiani, 2014).

Hasil Riset Kesehatan Dasar tahun 2013, menunjukkan bahwa perokok laki-laki usia diatas 15 tahun cenderung meningkat dari $34,2 \%$ pada tahun 2007 menjadi 36,3\% pada tahun 2013 dan 2,1\% perempuan masih menghisap rokok pada tahun 2013, 1,4\% terdapat umur perokok 10-14 tahun, 9,9\% pada kelompok tidak bekerja, dan 32,3\% pada kelompok kuintil indeks kepemilihan terendah. Sedangkan rata-rata jumlah batang rokok adalah sekitar 12,3 batang, bervariasi dari yang terendah 10 batang di Yogyakarta dan tertinggi di Bangka Belitung 18,3 batang (Balitbang, 2014).

Tarwoto dkk., (2012), menyatakan bahwa saudara dan orang tua sangat berpengaruh pada prilaku merokok remaja dan menyebabkan faktor keterlanjutan pada perilaku merokok. Berdasarkan data Global Youth Tobacco Survey (GYTS) (2009), 89,3\% remaja indonesia melihat iklan rokok di billboard, 76,6\% di media cetak dan 7,7\% pernah menerima rokok gratis. Sementara studi Komnas Anak (2007), menunjukkan bahwa $70 \%$ remaja mengaku mulai merokok karena terpengaruh oleh iklan, 77\% mengaku iklan menyebabkan mereka untuk terus merokok, dan 57\% mengatakan iklan mendorong mereka untuk kembali merokok setelah berhenti.

Pada anak usia remaja merokok dengan kemauan sendiri disebabkan karena penasaran untuk mencoba cita rasa seperti (menthol, cappuccino, dan teh hitam) yang dijanjikan oleh iklan rokok serta harga yang murah dan mudah di dapat. Selain itu remaja ingin menunjukkan bahwa ia telah dewasa atau merasa sudah tua dengan merokok, rasa ingin tahu besar, serta merokok dianggap memudahkan pergaulan. Umumnya bermula dari perokok pasif kemudian menjadi perokok aktif. Semula hanya melihat dan mencobacoba kemudian ketagihan akibat nikotin, sifat gengsi dari pemakai rokok dan agar terlihat hebat atau gagah juga awal dari rasa ingin mencoba (Hilda, 2015).

Bahaya merokok berpengaruh buruk terhadap remaja, terutama pada fisiknya, seperti yang dijelaskan oleh Depkes RI (2004) yaitu:" Rokok pada dasarnya merupakan pabrik bahan kimia berbahaya". Saat batang 
rokok terbakar, maka asapnya menguraikan sekitar 4000 bahan kimia dengan tiga komponen utama, yaitu: nikotin yang menyebabkan ketergantungan/adiksi, tar yang bersifat karsinogenik, dan karbon monoksida yang aktivitasnya sangat kuat terhadap hemoglobin sehingga kadar oksigen dalam darah berkurang. Efek merokok tidak hanya memengaruhi kesehatan perokok saja, tetapi juga memengaruhi kesehatan orang sekitarnya yang tidak merokok, karena terpapar asap rokok tersebut yang disebut perokok pasif (Tarwoto dkk., 2012).

Pemerintah telah melakukan upaya dalam mencegah dan mengendalikan konsumsi tembakau, salah satunya adalah dengan menetapkan Kawasan Tanpa Rokok (KTR). KTR diberlakukan di Fasilitas layanan kesehatan, tempat proses belajar, tempat ibadah, angkutan umum selain itu dengan adanya Iklan Layanan Masyarakat (ILM) melalui media cetak dan elektronik diharapkan mampu membudayakan kebiasaan hidup tanpa rokok. lebih lanjut kepada mitra kesehatan untuk ikut mensukseskan upaya promotifpreventif terkait pengendalian tembakau, dari dampak buruk kesehatan akibat konsumsi tembakau, dan sebagai panutan perilaku hidup bersih dan sehat dalam keluarga, lingkungan, dan masyarakat (Kemenkes R.I., 2015).

Menurut pasal 4 (1) Permenkes No 28 tahun 2013, sebuah perusahaan harus membagi produk tembakaunya kedalam lima kelompok, masing-masing mendapatkan satu lebel berbeda. Lima lebel tersebut antara lain; gambar kanker mulut dengan tulisan "merokok sebabkan kanker mulut", gambar orang merokok dengan asap yang membentuk tengkorak dengan tulisan "merokok membunuhmu", gambar kanker tenggorokan dengan tulisan "merokok sebabkan kanker tenggorokan", gambar orang merokok dengan anak di dekatnya dengan tulisan "merokok dekat anak berbahaya bagi mereka", kemudian gambar paru-paru yang menghitam karena kanker dengan tulisan, " merokok sebabkan kanker paru-paru dan bronchitis kronis". Sehingga dengan demikian dapat mengurungkan niat bagi seorang untuk merokok (Iswanto, 2015).

Mengatasi dan mencegah perilaku merokok pada keluarga atau remaja dapat dilakukan tindakan medis Nicotine Replacement Therapy (NRT), yaitu dengan pemberian transdermal, permen karet nikotin, tablet hisap, tablet sublingual, inhaler, dan semprot hidung. Permen karet nikotin juga merupakan produk yang juga mudah di untuk di konsumsi. Berbagai penelitian sudah mengungkapkan bahwa permen karet nikotin bisa untuk menghilangkan ketergantungan pada nikotin dari rokok, kandungan pemanis di dalam permen karet nikotin bisa menghentikan kebiasaan merokok. Penelitian telah menunjukkan bahwa rasa yang sangat intens dapat mengurangi kebutuhan untuk merokok (Gayatri \& Susanto, 2012).

Banyak cara untuk berhenti merokok, salah satunya dengan menguatkan tekad. Namun menguatkan niat dan tekad saja 
Siska Mayang Sari ${ }^{1}$, Trisna ${ }^{2}$, T. Abdur Rasyid ${ }^{3}, K_{0}$. Ansumsi Permen Susu Mempengaruhi Penurunan Konsumsi Rokok Pada Remaja

tidaklah cukup. Berkonsultasi dengan dokter dan sharing dengan teman-teman untuk berhenti merokok merupakan salah satu bentuk motivasi yang baik. Selain itu ada beberapa cara yang menyenangkan yaitu dengan makanan. Diantaranya dengan susu atau produk susu, Tidak begitu banyak yang mengetahui bahwa susu juga dapat membantu seseorang untuk berhenti merokok. dalam penelitian Gayatri \& Susanto tahun 2012 disebutkan bahwa penelitian oleh Duke University mengungkapkan bahwa perokok yang minum segelas susu sebelum merokok tidak akan menyukai rasa rokok mereka, karena rasa rokok menjadi pahit. Kemudian dengan sayuran tertentu seperti seledri, timun, dan terong juga meninggalkan rasa pahit jika dimakan sebelum merokok. Beberapa ahli menyatakan bahwa makan banyak sayuran ini dapat mengurangi intensitas ketergantungan nikotin. Mengkonsumsi buah seperti Jeruk, lemon, dan yang mengandung vitamin $\mathrm{C}$ juga dapat menjadi sebagai pembangkit tenaga. Berikutnya adalah ginseng, giseng yang telah terbukti untuk mencegah pelepasan nikotin yang diinduksi dari dopamin neotransmitter. Namun sebaiknya tidak di gunakan untuk sehari-sehari, tetapi dapat digunakan 3 - 4 kali dalam sebulan. Mengunyah permen karet bebas gula adalah cara yang baik untuk menjaga mulut agar tetap sibuk (Ilhamdi, 2015).

Perilaku merokok pada remaja sangat mempengaruhi gangguan dan masalah kesehatan, terlebih bagi anak usia remaja yang masih menimba ilmu di sekolah. Namun masih begitu banyak anak usia remaja yang merokok dengan alasan tersendiri. Hal ini sangat berpengaruh bagi remaja yang masih sekolah karena dampak dari merokok bisa menurunkan konsentrasi belajar, dan dapat menyebabkan berbagai penyakit seperti kanker paru-paru, penyakit jantung, dan masih banyak penyakit lainnya. Kerugian mengkonsumsi rokok dapat mempengaruhi aktivitas belajar, kerugian waktu, dan kerugian materi. Walaupun mengetahui dampak yang diakibatkan dari merokok, namun bagi mereka yang mengkonsumsi rokok masih saja mengkonsumsinya dan tidak mengetahui cara mengurangi konsumsi dan berhenti merokok. Mengkonsumsi susu selain baik untuk kesehatan, susu juga dapat merusak rasa rokok karena kandungan laktosa pada susu membuat rasa pahit yang bisa membuat perokok tidak ingin merokok lagi. Hal ini harus di kembangkan dalam mencegah atau mengurangi konsumsi rokok bagi seseorang. Oleh karena itu peneliti tertarik untuk melakukan penelitian "penelitian ini bertujuan apakah ada Pengaruh konsumsi permen susu terhadap penurunan konsumsi rokok pada remaja.

\section{METODOLOGI}

Penelitian ini adalah penelitian kuantitatif dengan menggunakan desain Quasi Experiment dengan rancangan pretest-posttest with control group. 
Tabel 1

Rancangan Penelitian pretest-posttest with control group.

\begin{tabular}{lccc}
\hline & $\begin{array}{c}\text { Pre } \\
\text { test }\end{array}$ & perlakuan & $\begin{array}{c}\text { Post } \\
\text { Test }\end{array}$ \\
\hline $\begin{array}{l}\text { Kelompok } \\
\text { Eksperimen }\end{array}$ & 01 & $\mathrm{X}$ & 02 \\
\hline Kelompok Kontrol & 01 & $(-)$ & 02 \\
\hline
\end{tabular}

Pada rancangan ini, kesimpulan mengenai efek perbedaan antara program intervensi) satu dengan yang lainnya dapat dicapai dengan menggunakan kelompok kontrol (Notoatmodjo, 2010).

Keterangan :

$\mathrm{X}$ : kelompok yang mendapat intervensi

(eksperimen) perlakuan dengan

menggunakan permen susu.

(-) : kelompok pembanding (kontrol) tidak mendapat perlakuan.

1 : Pretest bagi kedua kelompok.

02 : Postest bagi kedua kelompok.

Sampling adalah suatu proses dalam menyeleksi porsi yang akan menjadi sampel dalam populasi yang nantinya dapat mewakili populasi tersebut (Setiadi, 2013). Jumlah besar sampel dalam penelitian ini adalah dengan menggunakan Stratified random sampling yaitu pengambilan sampel secara acak berdasarkan strata (tingkatan) yang ada dalam populasi. Dengan jumlah sampel 32 orang.

Pengumpulan data adalah suatu proses pendekatan kepada subyek dan proses pengumpulan karakteristik subyek yang diperlukan dalam penelitian (Nursalam, 2008).
Adapun langkah-langkah dalam proses pengumpulan data adalah sebagai berikut:

a. Peneliti mengurus perizinan kepada pihak sekolah, setelah memperoleh izin kemudian peneliti memilih sampel penelitian yakni remaja perokok.

b. Remaja yang bersedia menjadi responden diminta untuk menandatangani lembar persetujuan untuk menjadi responden dan juga persetujuan dari orang tua.

c. Setelah mendapatkan persetujuan dari orang tua/wali dan responden, peneliti memberikan kuesioner kepada responden yang berisikan data karakteristik responden dan beberapa pertanyaan.

d. Peneliti membagi responden menjadi dua kelompok yaitu kelompok eksperimen dan kelompok kontrol yang dipilih secara random dengan sistem cabut undian. Nomor ganjil untuk kelompok eksperimen, dan nomor genap untuk kelompok kontrol.

e. Pada kelompok eksperimen dan kelompok kontrol diberikan kuesioner dan lembar observasi terlebih dahulu sebelum penelitian dimulai.

f. Untuk kelompok eksperimen mendapatkan pemberian permen susu setiap 3 hari sekali untuk dikonsumsi 3 hari kedepan hingga sampai 14 serta pemeriksaan pengisian lembar observasi.

g. Untuk kelompok kontrol tidak mendapatkan intervensi tetapi pada hari ke 15 mengumpulkan lembar observasi kepada peneliti. 


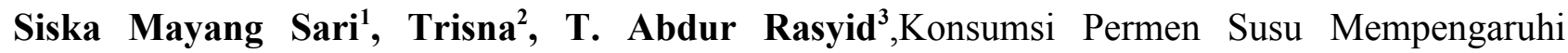
Penurunan Konsumsi Rokok Pada Remaja

Pengolahan data dilakukan dengan memeriksa lembar observasi jumlah konsumsi rokok responden nilai pretest dan posttest digunakan peneliti untuk mengetahui apakah ada perbedaan jumlah konsumsi rokok sebelum dan sesudah dilakukan pemberian permen susu. Analisis univariat dilakukan dengan menggunakan statistik deskriptif. Sedangkan untuk analisis bivariat dilakukan pengolahan dengan menggunakan uji paired $t$ test, Wilcoxon, dan Mann whitney.

\section{HASIL}

\section{Analisa Univariat}

Tabel 1.

Karakteristik pasien

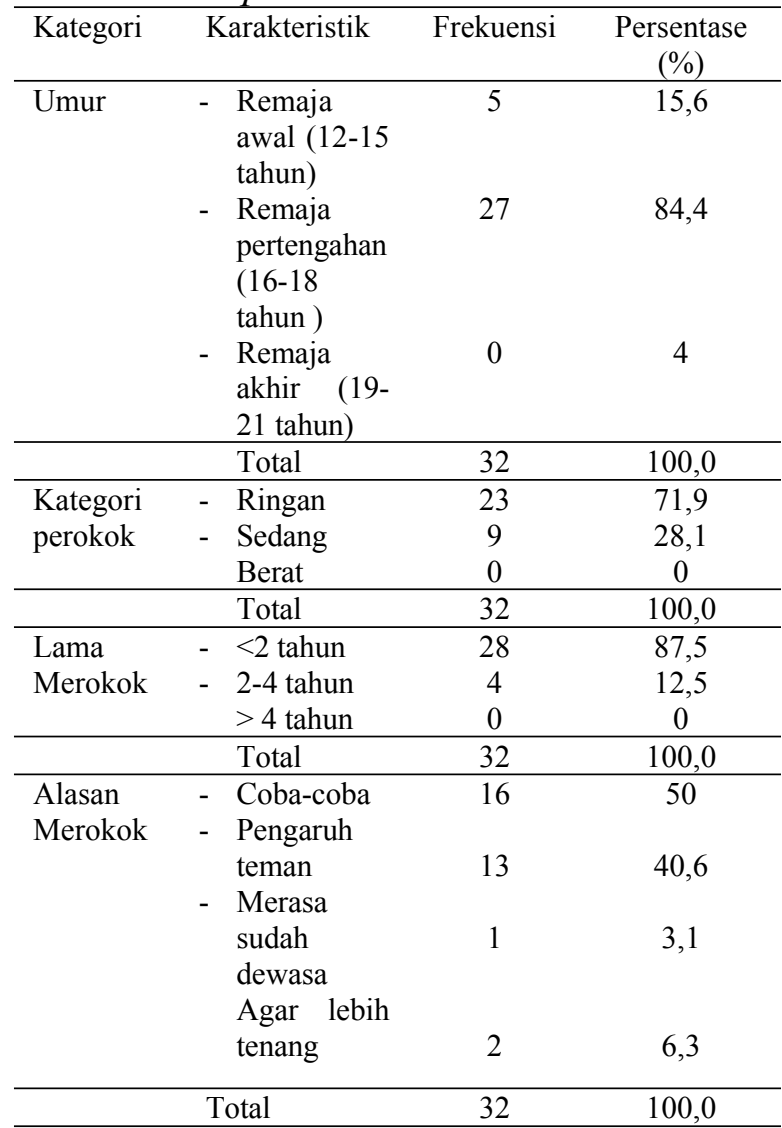

Hasil analisa univariat pada karakterikstik responden pada tabel 1 menunjukkan mayoritas responden berada pada rentang usia remaja pertengahan sebanyak 27 orang $(84,4 \%)$, mayoritas responden berada pada kategori perokok ringan sebanyak 23 orang $(71,9 \%)$, mayoritas lama usia merokok responden $<2$ tahun sebanyak 28 orang $(87,5 \%)$ dan mayoritas alasan responden merokok karena coba-coba sebanyak 16 responden $(50,0 \%)$.

Tabel 2

Konsumsi rokok sebelum dan sesudah konsumsi permen susu pada kelompok eksperimen

\begin{tabular}{lllllll}
\hline Variabel & Mean & SD & $\begin{array}{l}\text { Media } \\
\mathrm{n}\end{array}$ & Min & $\begin{array}{l}\text { Mak } \\
\mathrm{s}\end{array}$ & Range \\
\hline Konsum & & & & & & \\
si rokok & & & & & & \\
\hline Pretest & 7,31 & 4,332 & 6 & 2 & 16 & 14 \\
Posttest & 4,69 & 4,615 & 3 & 0 & 14 & 14 \\
\hline
\end{tabular}

Hasil uji normalitas pada kelompok eksperimen didapatkan nilai pada saat pretest $\alpha 0,058$ yang berarti data berdistibusi normal $\geq$ $(0,05)$, dan posttest didapatkan nilai $\alpha 0,011$ yang berarti data tidak berdistribusi normal $\leq$ $\alpha(0,05)$. Tabel 2 menunjukkan rata-rata konsumsi rokok pada kelompok eksperimen sebelum diberikan intervensi adalah 7,31 dengan nilai median 6 nilai SD 4,332, dan nilai Range 14. Setelah diberikan intervensi konsumsi permen susu selama 14 hari rata-rata konsumsi rokok menurun menjadi 4,69 dengan nilai median 3 nilai SD 4,615 dan nilai Range 14. Sebelum diberikan intervensi, konsumsi rokok tertinggi adalah 16 batang perhari dan yang paling rendah 2 batang perhari. Setelah diberikan intervensi dengan mengkonsumsi permen susu selama 14 hari, jumlah konsumsi rokok tertinggi menjadi 14 batang perhari dan 
yang paling rendah adalah 0 (tidak ada konsumsi).

Tabel 3

Konsumsi rokok sebelum dan sesudah tanpa konsumsi permen susu pada kelompok kontrol

\begin{tabular}{lllllll}
\hline Variabel & $\begin{array}{l}\text { Me } \\
\text { an }\end{array}$ & SD & $\begin{array}{l}\text { Med } \\
\text { ian }\end{array}$ & $\begin{array}{l}\text { M } \\
\text { in }\end{array}$ & $\begin{array}{l}\text { Mak } \\
\text { s }\end{array}$ & $\begin{array}{l}\text { Ran } \\
\text { ge }\end{array}$ \\
\hline $\begin{array}{l}\text { Konsum } \\
\text { si rokok }\end{array}$ & & & & & & \\
\hline Pretest & 7,31 & 4,045 & 8 & 14 & 2 & 16 \\
Posttest & 7,13 & 4,177 & 7,5 & 15 & 1 & 16 \\
\hline
\end{tabular}

Berdasarkan hasil uji normalitas pada kelompok kontrol didapatkan nilai pada saat pretest $\alpha 0,362$ yang berarti data berdistibusi normal $\geq(0,05)$, dan posttest didapatkan nilai a 0,696 yang berarti data berdistribusi normal $\geq \alpha(0,05)$.

Tabel 3 menunjukkan bahwa rata-rata konsumsi rokok pada kelompok kontrol pada saat pretest adalah 7,31 dengan nilai median 8 nilai sd 4,045 dan range 14. dan setelah 14 hari tanpa diberikan intervensi rata-rata konsumsi rokok menjadi 7,13 dengan nilai median 7,50 nilai sd 4,177 dan range 15 . Pada saat pretest, konsumsi rokok tertingi adalah 16 batang perhari dan yang terendah adalah 2 batang perhari. Setelah 14 hari tanpa diberikan intervensi, konsumsi rokok responden yang paling tinggi adalah 16 batang perhari dan yang terendah adalah 1 batang perhari.

\section{Analisa Bivariat}

Analisa bivariat menggunakan uji dependent sample $t$ test dan independent sample $t$ test. Jika test of normality menunjukkan data berdistribusi tidak normal,

maka dilakukan uji alternatif yaitu uji Wilcoxon dan uji Mann Whitney. Uji Wilcoxon dan Mann Whitney digunakan untuk membandingkan nilai penurunan jumlah konsumsi rokok antara kelompok eksperimen dan kelompok kontrol. Uji statistik menggunakan kemaknaan $(\alpha) \quad 0.05$ dan confidence interval (CI) 95\%. Permen susu berpengaruh terhadap penurunan konsumsi rokok jika nilai $\mathrm{p}$ value $\leq 0.05(\alpha)$.

Tabel 4

Rerata penurunan konsumsi rokok sebelum dan sesudah konsumsi permen susu pada kelompok eksperimen

\begin{tabular}{lcccc}
\hline $\begin{array}{l}\text { Kelompok } \\
\text { Eksperimen }\end{array}$ & Mean & SD & SE & $\mathrm{P}^{\text {value }}$ \\
\hline Pretest & 7,31 & 4,332 & 1,083 & 0,000 \\
Posttest & 4,69 & 4,615 & 1,154 & \\
\hline
\end{tabular}

Dari tabel 4 dapat diketahui bahwa pada kelompok eksperimen diperoleh nilai rata-rata (mean) sebelum diberi intervensi adalah 7,31, sedangkan setelah diberikan intervensi dengan konsumsi permen susu konsumsi rokok menurun menjadi 4,69. Hasil uji statistik didapatkan nilai $\mathrm{p}$ value $=0,000$ dimana $\mathrm{p} \leq \alpha$ $(0,05)$, berarti terdapat perbedaan rata-rata yang signifikan antara jumlah konsumsi rokok sebelum dan sesudah mengkonsumsi permen susu pada kelompok eksperimen.

Tabel 5

Rerata penurunan konsumsi rokok sebelum dan sesudah tanpa konsumsi permen susu pada kelompok kontrol

\begin{tabular}{lllll}
$\begin{array}{l}\text { Kelom } \\
\text { pok }\end{array}$ & Mean & SD & SE & $\mathrm{P}^{\text {value }}$ \\
Kont & & & & \\
Rol & & & & \\
\hline Pretest & 7,31 & 4,045 & 1,011 & \\
Postte & 7,13 & 4,177 & 1,044 & 0,083 \\
st & & & &
\end{tabular}




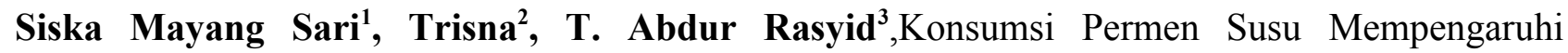
Penurunan Konsumsi Rokok Pada Remaja

Dari tabel 5 didaptakan data bahwa ratarata (mean) konsumsi rokok pada kelompok kontrol tanpa diberikan intervensi adalah 7,31, dan setelah 14 hari tanpa diberikan intervensi, rata-rata konsumsi rokok menjadi 7,13 dengan nilai $\mathrm{p}$ value $=0,083$ dimana nilai $\mathrm{p} \geq \alpha(0,05)$, berarti tidak terdapat perbedaan rata-rata yang signifikan antara jumlah konsumsi rokok sebelum dan sesudah tanpa mengkonsumsi permen susu pada kelompok kontrol.

Tabel 6

Perbedaan rerata penurunan konsumsi rokok pada kelompok eksperimen dan kelompok kontrol sesudah konsumsi permen susu

\begin{tabular}{lcccc}
\hline & Mean & SD & SE & $\mathrm{P}^{\text {value }}$ \\
\hline $\begin{array}{l}\text { Ekspe } \\
\text { rimen }\end{array}$ & 2,63 & 1,025 & 0,256 & \\
$\begin{array}{l}\text { Kont } \\
\text { Rol }\end{array}$ & 0,19 & 3,445 & 0,101 & 0,000 \\
\hline
\end{tabular}

Berdasarkan tabel 6 diatas diketahui bahwa rata-rata penurunan konsumsi rokok setelah diberikan intervensi pada kelompok eksperimen adalah 2,63, sedangkan pada kelompok kontrol diperoleh rata-rata penurunan setelah diberikan intervensi adalah 0,19 dengan nilai $\mathrm{p}$ value $=0,000$, berarti $\mathrm{p}$ value $\leq \alpha(0,05)$, sehingga terdapat perbedaan yang signifikan antara penurunan konsumsi rokok kelompok eksperimen dibandingkan kelompok kontrol. Perbedaan hal ini dapat disimpulkan bahwa H0 ditolak, berarti konsumsi permen susu berpengaruh terhadap penurunan konsumsi rokok pada remaja.

\section{PEMBAHASAN}

Berdasarkan hasil penelitian yang dilakukan pada remaja perokok di SMAN menunjukkan responden yang paling banyak berdasarkan umur adalah (remaja pertengahan) sebanyak 27 orang $(84,4 \%)$, dan paling sedikit pada umur (remaja awal) berjumlah 5 orang $(15,6 \%)$. Hal ini dikarenakan siswa yang menjadi sampel adalah siswa yang berada di kelas X dan XI dengan usia 15-18 tahun.

Umur merupakan salah satu faktor penting yang mempengaruhi merokok. Usia ini telah mampu berpikir secara abstrak dan mampu memberi alasan secara rasional. Setiap perilaku dan kebiasaan yang terlihat saat dewasa biasanya dimulai pada usia ini. Salah satu perilaku tersebut adalah merokok (Proverawati \& Rahmawati, 2012).

Selain umur, perilaku merokok pada remaja tidak terlepas dari pengaruh orang tua, pengaruh teman, faktor kepribadian, dan pengaruh iklan. Berbagai fakta mengungkapkan bahwa bila semakin banyak remaja yang merokok, maka semakin besar kemungkinan teman-temannya adalah perokok dan demikian sebaliknya. Gambaran bahwa perokok adalah lambang kejantanan atau glamour, membuat remaja sering kali terpicu untuk mengikuti perilaku seperti yang ada di dalam iklan tersebut. Dari fakta tersebut ada dua kemungkinan yang terjadi. Pertama, remaja tadi terpengaruh oleh teman-temannya atau bahkan teman-teman remaja ters ini sebut di pengaruhi oleh remaja tersebut, hingga akhirnya mereka semua menjadi perokok. Data menunjukkan dari $87 \%$ remaja perokok, mempunyai sekurang-kurangnya satu atau lebih sahabat yang perokok, begitu pula 
dengan remaja bukan perokok. (Tarwoto dkk, 2012).

Pada penelitian ini sendiri mayoritas responden mengaku alasan merokok karena coba-coba sebanyak 16 responden, artinya dalam hal ini responden merokok karena dikarenakan faktor kepribadian atau rasa ingin tahu yang besar.

Jaya (2009), menyatakan tahap merokok pada remaja terdapat beberapa tahap, yaitu: (1) tahap prepatory, seseorang mendapatkan gambaran yang menyenangkan mengenai merokok. Kemudian (2) tahap initation, dimana tahap perintisan merokok yaitu tahap apakah seseorang akan meneruskan ataukah tidak terhadap perilaku merokok. Selanjutnya (3) tahap becoming a smoker, yaitu apabila seseorang telah menkonsumsi rokok sebanyak 4 batang perhari. Dan (4) tahap maintenance of smoking, yaitu tahap ini merokok sudah menjadi salah satu bagian dari cara pengaturan diri (self regulating).

Dari penelitian diatas, peneliti berasumsi bahwa umur merupakan salah satu faktor penting yang mempengaruhi usia remaja merokok. Kategori perokok ringan terbanyak karena kemungkinan remaja ini pada tahap initiation atau becoming a smoker. Sedangkan lama usia merokok kemungkinan bisa dikarenakan faktor lingkungan.

Berdasarkan hasil penelitian yang diperoleh dari 16 responden pada kelompok eksperimen didapatkan nilai rata-rata konsumsi rokok sebelum dan sesudah diberikan intervensi terjadi penurunan nilai rata-rata 7,31 menjadi 4,69 dengan nilai $p$ adalah 0,000 atau $\leq \alpha(0,05)$, sedangkan pada kelompok kontrol didapatkan nilai rata-rata tanpa diberikan intervensi dari 7,31 menjadi 7,13 dengan nilai $\mathrm{p}$ adalah 0,083 atau $\geq \alpha$ (0.05). Hal ini menunjukkan bahwa terdapat perbedaan yang signifikan antara konsumsi rokok sebelum dan sesudah pada kelompok eksperimen. Pada kelompok kontrol didapat nilai $\mathrm{p}$ adalah 0,083 atau $\mathrm{p} \geq \alpha(0,05)$ artinya tidak terdapat perbedaan yang signifikan sebelum dan sesudah pada kelompok kontrol.

Berdasarkan penelitian diatas, peneliti berasumsi bahwa penurunan konsumsi rokok antara kedua kelompok tersebut berbeda. Hal ini dikarenakan bahwa kelompok kontrol tidak diberikan intervensi mengkonsumsi permen susu, hanya melakukan aktivitas sesuai kebiasaan yang berkemungkinan tidak mengubah jumlah konsumsi rokok.

Beberapa cara mengatasi kebiasaan merokok diantaranya dengan NRT, susu dan dengan subtitusi, Karena hal ini, mengkonsumsi permen susu juga dapat untuk menurunkan jumlah konsumsi rokok, karena mengkonsumsi permen juga dapat mengalihkan keinginan seseorang untuk merokok (Sekarsari, 2016).

Subtitusi atau pengganti yang dapat mengurangi kecanduan rokok diantaranya yaitu dengan mengkonsumsi daun mint, permen karet rendah gula, coklat hitam, jahe, pisang, dan susu full cream. Aroma daun mint dapat meningkatkan aktifitas otak yang mengontrol kewaspadaan, selain daun mint 
Siska Mayang Sari ${ }^{1}$, Trisna ${ }^{2}$, T. Abdur Rasyid ${ }^{3}, K_{0}$. Ansumsi Permen Susu Mempengaruhi Penurunan Konsumsi Rokok Pada Remaja

permen karet rendah gula juga dapat meningkatkan konsentrasi dengan terjadinya peningkatan aliran darah ke otak. Coklat diduga banyak kandungan zat yang memungkinkan terjadinya reaksi kimia di otak, zat tersebut akan serotonin yang selanjutnya akan memicu perasaan yang nyaman seseorang. Selain itu jahe secara umum dikenal sebagai anti radang (inflamasi), vasodilatasi (memperlebar) pembuluh darah, memperbaiki pencernaan dan anti nyeri. Dalam penelitian terakhir jahe mempunyai efek mengurangi kecanduan merokok dengan cara kerja menurunkan kadar nikotin dalam plasma yang selanjutnya menurunkan ambang batas pengeluaran dopamin oleh nikotin. Pisang mengandung triptofan yang dapat meningkatkan suasana hati (mood) positif dan membuat merasa lebih bahagia, secara tidak langsung kandungan pisang ini akan membantu mengurangi keinginan merokok. Selanjutnya susu full cream yang terkenal sebagai penggemuk badan karena kandungan lemak jenuh dan utuh, kandungan lemaknya lebih banyak dibanding susu yang lain yaitu sekitar $13 \%$. Saat meminum susu full cream akan terjadi reaksi kimia pada lidah yang merupakan ikatan kompleks termasuk mempengaruhi sekitar mulut dan menyebabkan rasa pahit dan tidak menyenangkan saat merokok (Elfa, 2016).

Farmakoterapi untuk menghentikan kebiasaan merokok dengan memberikan nikotin dengan cara bukan melalui rokok, yaitu nicotine replacement therapy (NRT).
Nicotine replacement therapy adalah farmakoterapi yang paling banyak diteliti untuk menghentikan kebiasaan merokok. Penggunaan NRT bertujuan untuk menggantikan nikotin yang sebelumnya diperoleh dari rokok. Tiga mekanisme kerja utama NRT adalah mengurangi gejala putus nikotin, mengurangi efek penguatan nikotin dan memberikan efek yang sebelumnya didapatkan dari rokok. Nicotine replacement therapy terdiri dari enam bentuk sediaan diantaranya yaitu permen karet (gum) dan tablet hisap (lozenge) (Gayatri dkk, 2012). Namun pada penelitian oleh Duke University Amerika tahun 2007, dimana pada penelitian ini menggunakan berbagai makanan seperti, sayuran, buah-buahan dan susu. Hasil penelitian ini menunjukkan susu berpengaruh besar dapat membuat rasa rokok menjadi pahit, sehingga perokok tidak ingin merokok lagi (Ilhamdi, 2015).

Dari hasil uji Mann-Whitney untuk konsumsi rokok setelah mengkonsumsi permen susu pada kelompok eksperimen dan kontrol diperoleh nilai $\mathrm{p}$ adalah 0,000 atau $\mathrm{p} \leq$ $\alpha(0,05)$. Hal ini menunjukkan permen susu berpengaruh terhadap penurunan jumlah konsumsi rokok pada remaja.

Berbagai cara untuk menurunkan dan menghentikan kebiasaan merokok diantaranya yaitu dengan makanan, NRT, permen karet nikotin, dan susu (Gayatri, dkk, 2012). Selain itu berpuasa, olahraga, dan pola hidup sehat juga dapat menghentikan kebiasaan merokok. Kate Janse Van Rensburg di University of 
Exter Inggris mengungkapkan olahraga merupakan alternatif bagi perokok yang ingin berhenti total dari kebiasaan menghisap rokok. Selanjutnya pola hidup sehat seperti mengkonsumsi buah-buahan, sayuran, susu, konsumsi air yang banyak dan menghindari zat-zat yang merusak seperti alkohol, narkoba, dan sejenisnya (Satiti, 2009).

Dengan demikian pada penelitian ini dapat disimpulkan bahwa mengkonsumsi permen susu dapat menurunkan konsumsi rokok seseorang. Hal ini dikarenakan dengan mengkonsumsi permen susu sangat mudah dilakukan serta memberikan tenggang waktu bagi perokok untuk merokok kembali sehingga perokok bisa untuk menurunkan jumlah konsumsi rokok perhari. Oleh sebab itu konsumsi permen susu berpengaruh untuk menurunkan konsumsi rokok yang dapat dijadikan sebagai terapi alternatif yang mudah untuk dilakukan.

\section{KESIMPULAN}

Berdasarkan hasil penelitian tentang pengaruh konsumsi permen susu terhadap penurunan konsumsi rokok pada remaja dapat diketahui bahwa terdapat pengaruh konsumsi permen susu terhadap penurunan konsumsi rokok pada kelompok eksperimen, dan tidak terdapat penurunan konsumsi rokok pada kelompok kontrol. Sedangkan pada kedua kelompok, ada perbedaan penurunan konsumsi rokok pada kelompok eksperimen yang mendapatkan intervensi pemberian permen susu, dan kelompok kontrol yang tidak mendapatkan intervensi pemberian permen susu. sehingga Ho ditolak, hal ini menunjukkan bahwa konsumsi permen susu berpengaruh menurunkan konsumsi rokok.

\section{SARAN}

1. Hasil penelitian ini khususnya untuk perkembangan ilmu keperawatan, bagi tenaga pengajar dan pelajar disarankan untuk dapat menggunakan permen susu sebagai salah satu bentuk terapi alternatif nonfarmakologis.

2. Penelitian ini dapat di sosialisasikan kepada remaja perokok dan dapat mensubtitusikan atau mengganti rokok dengan permen susu untuk menurunkan konsumsi rokok agar tercapainya pembelajaran yang lebih baik.

\section{DAFTAR PUSTAKA}

Adystiani, R. Y. (2014). Hasil riset WHO, rokok bunuh 6 juta orang per Tahun, Tabloid Bintang Aura, hlm. 1-5. Diperoleh dari http://www.aura.co.id/articles/Kesehatan/ 238-hasil-riset-who-rokok-bunuh-6-jutaorang-per-tahun

Balitbang. (2014). Riset kesehatan dasar 2013. Diperoleh dari http://www.depkes.go.id/resources/downl oad/general/Hasil\%20Riskesdas \%202013.pdf

Elfa, M. M. (2016) Inilah yang harus dikonsumsi untuk mengurangi kecanduan rokok. Diperoleh dari http:// www.kompasiana.com

Gayatri, A. \& Susanto, A. D. (2012). Nicotine replacement therapy. CDK-189 (39), 2530. Diperoleh dari http://www.kalbemed.com/Portals/6/09/_1 89

Hilda. I. A. (9 April 2015). Bahaya rokok bagi generasi remaja. Diperoleh dari http://www.heibogor.com/index.php/post/ 


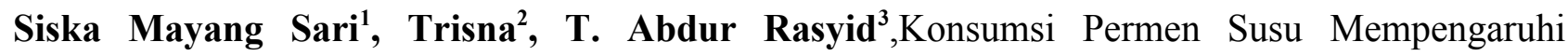
Penurunan Konsumsi Rokok Pada Remaja

detail/10694/Bahaya-Rokok-bagi-

Generasi-Remaja

Ilhamdi. (Januari, 2015). Berhenti merokok dengan makanan enak. Diperoleh dari http://1health.id/id/article/category/tips/be rhenti-merokok-dengan-makanan-enak386.html

Iswanto, H. (23 Juni 2015). Faktor internal dan eksternal yang mempengaruhi implementasi dan efektivitas peringatan bahaya merokok pada bungkus Rokok: Studi Kasus Indonesia. Kompasiana, hlm 1-8. Diperoleh dari http://www.kompasiana.com

Jaya, M. (2009). Pembunuh berbahaya itu bernama rokok. Yogyakarta: Riz'ma

Kemenkes, R.I. (2015). Wujudkan generasi muda bebas tembakau. Diperoleh dari http://www.depkes.go.id

Maharani, D. (1 Agustus 2015). 70 persen kematian kanker paru karena merokok. Diperoleh dari http://health.kompas.com

Notoatmodjo, S. (2010). Metodologi penelitian kesehatan. Yogyakarta: Rineka Cipta

Proverawati, A., \& Rahmawati. E. (2012). PHBS prerilaku hidup bersih \& sehat. Yogyakarta: Nuha Medika

Satiti, A. (2009). Strategi rahasia berhenti merokok. Yogyakarta: Data media

Sekarsari, B. (2016). Berhenti merokok dengan makanan enak. Diperoleh dari http://www.1health.id/id/article/category/s ehat-a-z/berhenti-merokok-denganmakanan-enak.html

Setiadi. (2013). Konsep dan praktek penulisan riset keperawatan, (2 Ed). Yogyakarta, Salemba Medika

Tarwoto., Aryani, A., Nuraeni, A., Miradwiyana, B., Tauchid, N. S., \& Aminah, S., et al. (2012). Kesehan remaja problem dan solusinya. Jakarta: Salemba Medika 